\title{
Penguatan Partai Politik sebagai Salah Satu Bentuk Pengadministrasian dan Pelembagaan Demokrasi
}

\author{
Aprista Ristyawati \\ Fakultas Hukum, Universitas Diponegoro \\ Email: aprista_r@yahoo.co.id
}

\begin{abstract}
This study aims to determine the strengthening of political parties as a form of administration and institutionalization of democracy. The formulation of the problem in this study are : what are the main problems of political parties in Indonesia at this time and how are efforts to strengthen political parties as a form of democratic institutionalization. The method of approach used in this study is normative juridical and analytical descriptive that is describing the object that is the main problem, from the depiction taken an analysis that is adapted to existing legal theories and put the law as a norm system building. The results of this study indicate that there are 3 (three) Main Problems of Political Parties in Indonesia that occur at this time, namely the weakening ideology of political parties, the recruitment system and the cadre formation patterns of less qualified political party members, the crisis of fundraising / fundraising of political parties. Efforts must be made to strengthen political parties as a form of institutionalization of democracy, namely by means of the ideology of political parties that must be strengthened, improve the quality and strengthen the recruitment system and regeneration patterns of political party members and there must also be a strengthening of the political party's fundraising system.
\end{abstract}

Keywords : Political Parties, institutionalization of democracy

\begin{abstract}
Abstrak
Penelitian ini bertujuan tuntuk mengetahui penguatan partai politik sebagai salah satu bentuk pelembagaan demokrasi. Metode pendekatan yang digunakan dalam penelitian ini adalah yuridis normatif dan bersifat deskriptif analitis yaitu menggambarkan objek yang menjadi pokok permasalahan, dari penggambaran tersebut diambil suatu analisa yang disesuaikan dengan teori-teori hukum yang ada dan meletakan hukum sebagai sebuah bangunan sistem norma. Hasil penelitian ini menunjukkan bahwa Ada 3 (tiga) Problem Utama Partai Politik di Indonesia yang terjadi pada saat ini, yaitu ideologi partai politik yang semakin melemah, sistem rekrutmen dan pola kaderisasi anggota partai politik yang kurang berkualitas, krisis pengumpulan dana / Fundraising pada partai politik. Upaya yang harus dilakukan untuk memperkuat Partai Politik sebagai salah satu bentuk pelembagaan Demokrasi yaitu dengan cara ideologi Partai Politik harus diperkuat, meningkatkan kualitas dan memperkuat sistem rekrutmen dan pola kaderisasi anggota partai politik dan juga harus ada penguatan sistem pengumpulan dana (Fundraising) Partai Politik.
\end{abstract}

Kata Kunci : Partai Politik, pelembagaan demokrasi 


\section{A. Pendahuluan}

Pada akhir dekade 18-an, di negara-negara Eropa Barat merupakan awal adanya perkembangan partai politik. Partai politik telah lahir spontan dan berkembang menjadi penghubung antara rakyat di satu pihak dan pemerintah di pihak lain, hal tersebut karena meluasnya gagasan bahwa rakyat merupakan faktor yang perlu diikutsertakan dan diperhitungkan dalam proses politik.

Dalam negara-negara yang menganut demokrasi, Partai politik merupakan salah satu bentuk pelembagaan demokrasi yang mana dianggap sebagai representasi resmi aspirasi rakyat. Partai politik menjadi penghubung antara proses-proses yang terjadi di pemerintahan dengan dinamika sosial yang terjadi di dalam masyarakat. Oleh karena itu, partai politik bisa dikatakan yang sebetulnya menentukan demokrasi di suatu negara. Pengertian Partai Politik menurut Undang-Undang Nomor 2 Tahun 2011 tentang Partai Politik, Partai Politik adalah organisasi yang bersifat nasional dan dibentuk oleh sekelompok warga negara Indonesia secara sukarela atas dasar kesamaan kehendak dan cita-cita untuk memperjuangkan dan membela keutuhan Negara Kesatuan Republik Indonesia berdasarkan Pancasila dan Undang-Undang Dasar Negara Republik Indonesia Tahun $1945^{1}$.

Pasca reformasi, kehidupan partai politik di Indonesia menunjukkan dinamika kelembagaan yang masih memerlukan pembenahan. Secara garis besar, berbagai problem partai politik yang ada di Indonesia ini utamanya adalah masalah pada ideologi partai. Hal tersebut dapat terlihat dari tingkah laku para elitenya yang cenderung bersikap pragmatis yang akhirnya menggiring partai untuk melakukan politik kartel. Politik kartel adalah kondisi politik dimana banyak partai politik bermetafora memainkan konsep ekonomi dalam kehidupan berpolitik. Perdebatan ideologi, gagasan, dan visi misi bukan lagi menjadi tolak ukur. Satu-satunya yang menjadi tolak ukur adalah kepentingan. Model partai kartel, menurut Katz dan Mair, tumbuh mengikuti modernisasi dan birokratisasi masyarakat. Perluasan pasar politik, pada satu sisi, dan munculnya agenda sosial baru berpusat pada isu-isu politik baru, pada sisi lain, melemahkan afiliasi pemilih terhadap partai tradisional ${ }^{2}$. Ciri dari partai yang sudah terkartelisasi dapat dipastikan bahwa perilaku partai politik di Indonesia cenderung ke arah perilaku yang terkartelisasi, yang berarti bahwa ideologi dan program partai dinomorsekiankan dna dikalahkan oleh

\footnotetext{
${ }^{1}$ Pasal 1 angka 1 Undang-Undang Nomor 2 Tahun 2011 Tentang Partai Politik

2 Yishai, Yael, 2001, "Bringing Society Back In: Post-Cartel Parties in Israel" dalam Party Politics, Vol. 7 , No. 6: hlm. 667-687.
} 
kepentingan yang pragmatis ${ }^{3}$. Berdasarkan latar belakang di atas maka yang menjadi pokok permasalahan yakni sebagai berikut: Pertama, Apa sajakah yang menjadi problem utama Partai Politik di Indonesia pada saat ini?, Kedua, Bagaimana upaya untuk memperkuat Partai Politik sebagai salah satu bentuk pelembagaan demokrasi ?

\section{B. Pembahasan}

\section{Problem Utama Partai Politik di Indonesia Pada Saat Ini}

Partai politik memiliki arti penting dalam sebuah sistem demokrasi perwakilan. Partai politik diyakini sebagai instrumen yang strategis bagi perkembangan demokrasi Indonesia di masa depan. Namun sejak runtuhnya rezim Orde Baru atau era reformasi terlihat adanya penurunan tingkat kepercayaan masyarakat terhadap partai politik . Partai politik mulai kehilangan arah dan tujuan. Sejak reformasi, kegairahan politik di Indonesia begitu tinggi. Banyak kelompokkelompok dalam masyarakat yang mendirikan partai politik sebagai konsekuensi dari kebebasan akan hak politik yang dipercaya akan membawa perubahan terhadap negara ini. Meskipun muncul berbagai reaksi terhadap eksistensi partai politik saat ini, berbagai pihak berharap demokrasi akan semakin baik apabila partai politik bisa lebih profesional, demokratis dan akuntabel.

Jika dianalisis permasalahan utama negara Indonesia pada era Orde Baru dengan era reformasi tentulah berbeda. Pada era Orde Baru dimana permasalahan utamanya ditimbulkan akibat pengekangan dan pembatasan hak politik warga negaranya, sedangkan pada era reformasi memiliki permasalahan yang ditimbulkan akibat pembebasan hak-hak politik tersebut. Dalam hal partai politik di Indonesia, terutama sejak Undang-Undang Nomor 3 Tahun 1999 tentang Partai Politik itu berlaku sangatlah dimungkinkan kembali dilaksanakannya sistem multipartai. Banyaknya partai politik peserta pemilu yang ikut meramaikan pesta demokrasi terbesar tersebut di satu sisi mencerminkan semangat demokrasi, namun ada hal-hal yang menimbulkan gejala yang mengkhawatirkan di sisi lainnya.

Banyak partai politik yang menjadikan pemilu pada saat itu sebagai ajang untuk memperoleh dan berbagi kekuasaan. Banyak ideologi politik dan basis sosial yang seharusnya diperjuangkan partai-partai tersebut luntur dengan sendirinya ketika para elite politik tersebut sudah masuk di pemerintahan ataupun sebagai wakil

\footnotetext{
${ }^{3}$ Muhadam Lalobo dan Teguh Ilham, 2017, Partai Politik dan Sistem Pemilihan Umum di Indonesia, Jakarta:Rajawali Pers, hlm.263
} 
rakyat, mereka sibuk memikirkan bagaimana mereka bisa bertahan pada jabatan yang telah diperoleh dan mengambil uang negara untuk menghidupi partainya bukannya memperjuangkan aspirasi rakyatnya.

Gejala yang nampak pada saat ini adalah adanya politik kartel, yang merupakan politik dimana partai dan aktivitasnya tidak lagi mengusung kepentingan konstituen atau kepentingan publik, tetapi mengurus diri sendiri dan politik menjadi profesi dalam dirinya. ${ }^{4}$ Berikut problem utama Partai Politik di Indonesia pada saat ini menurut penulis, antara lain :

\section{a. Ideologi Partai Politik yang semakin melemah}

Kata ideologi mengandung 2 (dua) pengertian, yaitu ideologi secara fungsional dan secara struktural. Secara fungsional dapat diartikan sebagai seperangkat gagasan tentang kebaikan bersama, atau tentang masyarakat dan negara yang dianggap paling baik. Sedangkan secara struktural, ideologi dapat diartikan sebagai sistem pembenaran, seperti gagasan dan formula politik atas setiap kebijakan dan tindakan yang diambil oleh penguasa. ${ }^{5}$ Dalam Negara Kesatuan Republik Indonesia,dengan berdasarkan Pancasila, maka masyarakat menjadi paham arah perjuangan partai-partai. Dengan adanya ideologi yang jelas pada setiap partai politik maka identitas setiap partai pun akan menjadi jelas sehingga masyarakat mudah untuk menentukan partai politik mana yang sesuai dengan ideologi mereka.

Kriteria yang dapat kita ketahui untuk mengetahui kelemahan ideologi partai politik yaitu dilihat dari perilaku dan karakter partai politik. Yang mana dapat diketahui melalui (1) Ideologi Partai Politik berdasarkan Anggaran Dasar (AD)/ Anggaran Rumah Tangga (ART) Partai tersebut, dokumen AD/ART merupakan statement formal partai politik yang berisi pernyataan ideologis, prinsip - prinsip yang abstrak, tujuan pokok partai, dan serangkaian program spesifik $^{6}$. Terkadang Ideologi yang tertulis secara formal AD/ART tidak mencerminkan ideologi partai tersebut. Pada kenyataannya banyak perilaku partai politik tidak sejalan dengan ideologi yang telah ditetapkan. Untuk

\footnotetext{
${ }^{4}$ Kuskridho, Ambardi, 2009, Mengungkap Politik Kartel: Studi tentang Sistem Kepartaian di Indonesia Era Reformasi, Jakarta:KPG, hlm.17

${ }^{5}$ Ramlan Surbakti, 2007, Memahami Ilmu Politik, Jakarta:Gramedia Widiasarana Indonesia, hlm. 32-33.

${ }^{6}$ Francesca Vassalo\&Clyde Wilcox, 2006, Part as a Carrier of Ideas, dalam Muhadi Sugiono dan Wawan Mas'udi, Peta Ideologi Partai Politik Peserta Pemilu 2009, Laporan Penelitian Hibah Riset Fakultas, Yogyakarta:Fakultas Ilmu Sosial dan Ilmu Politik UGM, hlm.6
} 
menentukan ideologi partai politik memanglah tidak mudah, hal ini karena banyak partai yang tidak menampilkan secara murni ideologi partainya seperti apa yang telah mereka tetapkan. (2) Perilaku Elite Partai Politik ketika menghadapi Pemilu. Salah satu contohnya adalah fenomena terjadinya koalisi partai pada tingkat pusat yang berbeda ideologi yang mana malah menimbulkan masalah. Banyak terjadi perbedaan pendapat dalam tubuh koalisi yang membuat jalan pemerintahan menjadi tidak efektif. Padahal, koalisi idealnya dibentuk dengan dasar kesamaan ideologi sehingga ketika koalisi tersebut berkuasa tidak akan terjadi banyak perselisihan yang ditimbulkan sehingga pemerintahan dapat berjalan secara efektif. Jika pembentukan koalisi tidak mempertimbangkan kesamaan ideologi maka akan berdampak kepada sulitnya pengambilan kebijakan karena terjadi perbedaan pendapat yang sangat tajam di antara partai koalisi.

\section{b. Sistem Pengadministrasian dan Rekrutmen Pola Kaderisasi Anggota Partai}

\section{Politik yang kurang berkualitas}

Sistem Rekrutmen dan Pola Kaderisasi Anggota Partai Politik pada saat ini cukup memprihatinkan. Banyak fenomena yang menimbulkan keraguan pada kader partai politik. Apabila sistem rekrutmen dan pola kaderisasi kader dilakukan dengan baik oleh setiap partai politik, maka tidak akan pernah ditemukan lagi fenomena berkhianat dari partai politik asalnya. Fenomena naturalisasi kader partai politik dari satu partai ke partai lain yang terjadi pada saat ini menunjukkan bahwa partai politik mengalami disfungsi dalam rekrutmen politik dan pola kaderisasi dan dianggap gagal dalam menanamkan ideologi partai kepada kadernya.

Sistem/pola rekrutmen dan kaderisasi yang semakin instan tersebut menambah penilaian negatif masyarakat terhadap partai politik. Partai politik lebih cenderung merekrut kader yang sudah jadi, bukan kader yang benar benar dibesarkan dan merasakan proses kehidupan berpartai dari masa yang pahit sampai menuju masa mencapai tujuan partai tersebut sehingga menimbulkan pola rekrutmen dan pola Kaderisasi Anggota Partai Politik yang kurang loyal dan berkualitas . Banyak politisi yang juga cenderung memanfaatkan nama besar partainya yang baru untuk memenangkan pemilu ketika partai yang lama gagal mengantarkan dirinya sebagai pemenang. 
Hal tersebut mencerminkan bahwa proses yang dilakukan para politisi untuk mendapatkan jabatan politik tidak lagi diorientasikan pada kepentingan publik, namun cenderung dipergunakan untuk memenuhi kepentingan yang sifatnya pribadi atau kelompok. Fenomena tersebut dapat menyebabkan proses seperti pembinaan, penyiapan, dan seleksi kader-kader politik tidak berjalan sebagaimana mestinya.

\section{c. Krisis Pengumpulan Dana / Fundraising pada Partai Politik}

Tersedianya sumber dana yang banyak dan lancar bagi sebuah partai politik merupakan suatu keharusan yang tidak dapat ditawar. Apabila sebuah partai mengalami krisis dalam hal pendanaan, maka dimungkinkan bagi partai tersebut untuk melakukan segala macam cara termasuk dengan menggadaikan ideologi partai sehingga berubah menjadi partai yang pragmatis atau partai yang menghalalkan berbagai cara.

Seperti yang kita ketahui, di dalam Pasal 34 Undang-Undang Nomor 2 Tahun 2011 tentang Partai politik menyebutkan bahwa sumber dana partai politik berasal dari iuran anggota partai politik, sumbangan yang sah menurut hukum, dan bantuan dari APBN/APBD. Perlu disadari, bagi partai politik ketika menjelang pemilihan umum memang semakin banyak mengeluarkan dana demi mendapatkan kemenangan di dalam pemilu tersebut, hal demikian tentu menjadi catatan yang perlu diperhitungkan oleh sebuah partai politik mengenai dana yang dimiliki oleh partai tersebut. Apalagi jika iuran dari anggota partai sangat minim, maka partai-partai cenderung untuk bergantung kepada Anggaran Pendapatan dan Belanja Negara (APBN) dan Anggaran Pendapatan dan Belanja Daerah (APBD) yang mana dana tersebut menjadi pendapatan utama partai. Sumbangan dana yang berasal dari APBN / APBD tersebut diberikan berdasarkan proporsi jumlah suara partai politik dalam perolehan kursi DPR RI, DPRD Provinsi dan DPRD Kabupaten / Kota. Sumbangan tersebut diberikan dengan tujuan agar memberikan pendidikan partai politik kepada anggota partai politik dan masyarakat yang pada kenyataannya di lapangan justru pendidikan partai politik tersebut tidak terlaksana, tentu hal tersebut dangat disayangkan.

Hal yang lebih memprihatinkan lagi yaitu adanya fenomena partai politik memanfaatkan kadernya yang memiliki posisi strategis dalam jabatan politik untuk mengumpulkan dana secara ilegal yang menjadikannya seolah -olah legal. 
Tidak dapat dipungkiri apabila ada institusi ataupun badan usaha negara yang dijadikan sebagai sapi perah. Fenomena yang terjadi tersebut merupakan realitas yang tentu dapat menjadikan citra yang buruk bagi partai politik dan tentu sangat mengancam keuangan negara.

Dengan tingginya kebutuhan partai politik akan pemasukan dana telah mendorong munculnya satu jenis partai baru, yaitu partai kartel ${ }^{7}$. Partai kartel tersebut muncul akibat dari ketidakmampuan partai - partai untuk mempertahankan sumber pendanaannya yang berasal dari iuran anggota ataupun masyarakat yang menjadi basis sosialnya. Dalam hal ini yang menjadi problem utama adalah ketergantungan partai politik pada dana yang berasal dari pemerintah tersebut telah mengubah watak dari partai politik itu sendiri. Partai politik seolah menjauhi masyarakat dan semakin dekat dengan negara atau pemerintah.

\section{Upaya Untuk Memperkuat Partai Politik sebagai Salah Satu Bentuk}

\section{Pengadministrasian Pelembagaan Sistem Demokrasi}

Bagi negara yang menganut sistem demokrasi seperti di Indonesia, peran dan fungsi partai politik tidak dapat diabaikan. Fungsi partai politik memiliki peran strategis sebagai jembatan antara kepentingan masyarakat terhadap sejumlah isu strategis yang berkaitan dengan kebijakan pemerintah. Partai politik lahir dan berkembang dalam suatu lingkungan yang saling mempengaruhi. Yang mana faktor kepemimpinan dan sistem kelembagaan partai politik menjadi hal yang sangat menentukan.

Keinginan untuk mewujudkan dunia politik yang penuh dengan berbagai aktivitas yang benar-benar mengarah kepada tujuan dari politik itu sendiri pada kenyataannya sangatlah berbanding terbalik dengan keadaan dunia perpolitikan saat ini yang mana penuh dengan berbagai macam penyimpangan - penyimpangan yang ada yang mana juga menimbulkan stigma negatif bagi politik itu sendiri. Oleh karena itu, dapat dilakukan beberapa upaya untuk memperkuat Partai Politik sebagai salah satu bentuk Pelembagaan Demokrasi yang ada di Indonesia ini yaitu sebagai berikut:

\section{a. Ideologi Partai Politik harus diperkuat}

Politik dan Ideologi merupakan dua hal yang tidak dapat dipisahkan. Begitu pula dengan partai politik, ideologi tidak dapat dipisahkan dan sangat berperan

\footnotetext{
${ }^{7}$ Kuskridho Ambardi, Op.cit, hlm.285.
} 
penting pada eksistensi suatu partai politik. Eksistensi partai politik merupakan akibat dari konsistennya suatu partai politik dalam menjalankan ideologinya. Hal tersebut menjadi tantangan bagi partai politik agar mampu membangun basis ideologi yang jelas, dapat diterima oleh masyarakat dan tentunya agar mampu menjawab setiap persoalan bangsa.

Untuk membangun kesan positif agar masyarakat dapat mengenal partai politik dan ideologinya dibutuhkan suatu komunikasi politik yang tepat dan efektif yaitu partai politik harus menciptakan setiap aktivitas dan program politiknya dengan pesan - pesan yang bersifat ideologis ${ }^{8}$. Banyaknya pertentangan antar ideologi yang terjadi saat ini tidaklah salah, asalkan dibingkai dengan semangat humanisme sehingga tidak menimbulkan kerugian di tengah masyarakat.

Lemahnya ideologi partai politik di Indonesia dewasa ini merupakan problem partai yang serius. Partai politik cenderung bersifat pragmatis dan menunjukkan gejala-gejala politik kartel. Hal ini jika dibiarkan saja, maka akan dikhawatirkan peran partai politik yang mana sebagai penyalur aspirasi rakyat menjadi terganggu. Salah satu cara untuk menguatkan partai politik dalam berideologi adalah menguatkan salah satu divisi dalam struktur organisasi partai politik, yaitu divisi Penelitian dan Pengembangan (Litbang).

Litbang merupakan suatu unit di dalam partai politik yang berperan dalam mengumpulkan, menganalisis, dan mendistribusikan informasi politik kepada semua jaringan organisasi partai politik yang terdapat di pusat maupun di daerah. Namun yang ditakutkan adalah apabila informasi politik tersebut dijadikan konsumsi pihak di luar partai politik tersebut, dalam hal ini seperti pesaing politik, media massa, jurnalis maupun masyarakat. Tentu dalam hal ini, peran Litbang yang menjadi pemberi informasi yang dapat dijadikan sebagai bahan dan dasar bagi kebijakan politik partai akan tercoreng. Pentingnya divisi Litbang dalam organisasi partai politik terletak dari keterkaitannya dalam upaya penterjemahan ideologi partai politik sehingga dapat dimengerti dan dipahami oleh masyarakat. Selain itu, Litbang juga berperan dalam menjaga konsistensi ideologi partai agar tidak mudah dipengaruhi dan dirusak oleh individu individu tertentu.

\footnotetext{
${ }^{8}$ Firmanzah, 2011, Mengelola Partai Politik, Jakarta:Yayasan Pustaka Obor Indonesia, hlm. 197.
} 
Pergeseran ideologi partai politik tidak hanya menjadi ancaman dari luar partai saja, namun tidak dapat dipungkiri terjadi dari sifat atau karakteristik pribadi seorang pemimpin partai yang mempengaruhi ideologi suatu partai. DI situlah peran penting divisi Litbang untuk menjada konsistensi ideologi partai politik. Sudah saatnya partai berani untuk menunjukkan jati diri partainya dengan cara bangga dengan ideologi yang dimiliki. Tanpa adanya ideologi, politik hanya menimbulkan gangguan bagi kadernya saat memegang kekuasaan. Oleh karena itu, partai politik juga harus menanamkan ideologi politik kepada para kadernya untuk mewujudkan cita - cita politik yaitu membangun sebuah struktur pemeirntahan yang mampu menciptakan kebaikan bersama.

b. Meningkatkan kualitas dan Memperkuat Sistem Rekrutmen dan Pola Kaderisasi Anggota Partai Politik

Untuk menghasilkan pemimpin yang berkualitas, peran partai politik di sini sangatlah diperlukan. Sistem rekrutmen dan pola kaderisasi anggota partai politik yang baik dapat dilihat dari kemampuan kader suatu partai dalam berkompetisi dengan kader yang berasal dari partai lain tentunya dengan kompetisi yang sehat. Rekrutmen politik merupakan tahap awal bagi partai politik dalam rangka regenerasi partai. Baik buruknya kualitas partai di masa yang akan datang ditentukan oleh sejauh mana partai berhasil merekrut orang orang terbaik.

Partai politik yang mempunyai posisi strategis dalam kehidupan demokrasi, saat ini perlu perbaikan di dalam sistem kaderisasinya. Ada beberapa hal yang perlu diperhatikan dalam menyiapkan kader partai politik yang baik, yaitu (1) Sistem yang ketat pada proses rekrutmen calon anggota partai politik, seleksi yang baik adalah seleksi yang menempatkan penilaian kompetensi sebagai indikator penilaian yang utama. (2) Adanya masa orientasi dan sosialisasi bagi anggota partai politik yang diterima, hal ini penting dalam rangka membekali para anggotanya untuk memahami dengan baik apa yang menjadi ideologi dan program - program partainya. (3) Setiap anggota partai politik diberikan pembinaan yang baik, yang menekankan pada masalah mental dan nilai-nilai moral agar mereka tidak mudah tergiur untuk melakukan hal - hal yang kurang terpuji. (4) Dalam mengisi jabatan politik, diutamakan untuk kader yang dapat menunjukkan kinerja, integritas serta loyalitas yang tinggi. Dengan cara 
tersebut dapat meminimalisir adanya kader - kader titipan yang kualitasnya belum tentu baik. (5) Harus ada batasan masa bhakti anggota partai, agar proses regenerasi berjalan dengan baik sehingga semangat pembaruan akan terus berkembang ke arah yang lebih baik. (6) Ada penerapan sanksi tegas kepada kader partai yang melakukan pelanggaran, untuk memberikan efek jera kepada kader tersebut dan menimbulkan simpati bagi masyarakat kepada partai karena partai konsisten menegakkan disiplin kepada para kadernya.

\section{c. Penguatan Sistem Pengumpulan Dana (Fundraising) Partai Politik}

Banyaknya partai politik yang terjebak ke dalam politik kartel menyebabkan partai semakin jauh dengan konstituennya. Hal tersebut menyebabkan partai politik mengalami kesulitan dalam pengumpulan dana yang berasal dari iuran anggotanya dan berakibat partai politik mendekatkan diri kepada para penyumbang bermodal besar untuk menutupi kebutuhan partainya. Padahal hal tersebut sangat berpotensi pada kemandirian partai dalam berpolitik karena dibalik sumbangan besar tersebut pasti terselip niat untuk bisa mengendalikan partai dnegan cara mempengaruhi kebijakan partai politik. Dalam hal ini, seharusnya partai politik harus melakukan pengelolaan keuangana partai politik secara terbuka, dengan cara menunjukkan daftar penyumbang dan membuat laporan tahunan secara rutin serta laporan pertanggungjawaban penggunaan dana negara juga harus dilakukan secara teratur sesuai dengan ketentuan yang berlaku agar terciptanya penguatan sistem fundraising di dalam partai politik tersebut.

\section{Kesimpulan}

Berdasarkan hasil pembahasan dan penelitian, penulis mengambil kesimpulan bahwa: Pertama, Ada 3 (tiga) Problem Utama Partai Politik di Indonesia yang terjadi pada saat ini, yaitu (1) Ideologi Partai Politik yang semakin melemah, Kriteria yang dapat kita ketahui untuk mengetahui kelemahan ideologi partai politik yaitu dilihat dari perilaku dan karakter partai politik, yang mana dapat diketahui melalui Ideologi Partai Politik berdasarkan Anggaran Dasar (AD)/ Anggaran Rumah Tangga (ART) Partai tersebut, dan dari Perilaku Elite Partai Politik ketika menghadapi Pemilu. Kedua, Sistem Rekrutmen dan Pola Kaderisasi Anggota Partai Politik yang kurang berkualitas, partai politik lebih cenderung merekrut kader yang sudah jadi, bukan kader yang benar - benar dibesarkan dan merasakan proses kehidupan berpartai dari 
masa yang pahit sampai menuju masa mencapai tujuan partai tersebut sehingga menimbulkan pola rekrutmen dan pola Kaderisasi Anggota Partai Politik yang kurang loyal dan berkualitas. (3) Krisis Pengumpulan Dana / Fundraising pada Partai Politik, ketergantungan partai politik pada dana yang berasal dari pemerintah tersebut telah mengubah watak dari partai politik itu sendiri. Partai politik seolah menjauhi masyarakat dan semakin dekat dengan negara atau pemerintah.

Upaya yang harus dilakukan untuk memperkuat Partai Politik sebagai salah satu bentuk pelembagaan Demokrasi yaitu dengan : (1) Ideologi Partai Politik harus diperkuat. (2) Meningkatkan kualitas dan Memperkuat Sistem Rekrutmen dan Pola Kaderisasi Anggota Partai Politik. (3) Penguatan Sistem Pengumpulan Dana (Fundraising) Partai Politik.

\section{DAFTAR PUSTAKA}

Ambardi, Kuskridho. 2009, Mengungkap Politik Kartel: Studi tentang Sistem Kepartaian di Indonesia Era Reformasi. Jakarta:KPG.

Firmanzah. 2011. Mengelola Partai Politik. Jakarta:Yayasan Pustaka Obor Indonesia.

Francesca Vassalo\&Clyde Wilcox. 2006. Part as a Carrier of Ideas, dalam Muhadi Sugiono dan Wawan Mas'udi, Peta Ideologi Partai Politik Peserta Pemilu 2009. Laporan Penelitian Hibah Riset Fakultas. Yogyakarta:Fakultas Ilmu Sosial dan Ilmu Politik UGM.

Muhadam Lalobo dan Teguh Ilham. 2017. Partai Politik dan Sistem Pemilihan Umum di Indonesia. Jakarta:Rajawali Pers.

Mukti Fajar ND dan Yulianto Achmad. 2007. Dualisme Penelitian Hukum.Yogyakarta: Pensil Komunika.

Surbakti, Ramlan. 2007. Memahami Ilmu Politik. Jakarta:Gramedia Widiasarana Indonesia.

Undang-Undang Nomor 2 Tahun 2011 tentang Partai Politik

Yael, Yishai. 2001. "Bringing Society Back In: Post-Cartel Parties in Israel" dalam Party Politics. Volume 7 Nomor 6. 